\title{
EECN: Analysis, Potency, Benefit for Students Knowledge and Attitude to
} Conserve Mangroves and Coral Reefs

\section{Diana Vivanti Sigit}

Universitas Negeri Jakarta, Indonesia, dianav@unj.ac.id

\section{Mieke Miarsyah}

Universitas Negeri Jakarta, Indonesia, mmiarsyah@unj.ac.id

\section{Ratna Komala}

Universitas Negeri Jakarta, Indonesia, asuryanda@unj.ac.id

\section{Ade Suryanda}

Universitas Negeri Jakarta, Indonesia, asuryanda@unj.ac.id

\section{Ilmi Zajuli Ichsan}

Universitas Negeri Jakarta, Indonesia, ilmizajuli95@gmail.com

\section{Rahmat Fadrikal}

Universitas Sultan Ageng Tirtayasa, Indonesia, fadrikal@gmail.com

The purpose of this study was to measure student knowledge and attitudes in conservation of mangroves and coral reefs, introducing and applying Environmental Education Community Network (EECN) to students in wider scale. The method used in this research is a descriptive method and used a survey for gathering data. Samples were selected with simple random sampling in several schools and Jakarta State University. The results showed Average score of knowledge students from all levels were with low category. Average score of attitudes students from all levels were with high category. Students' knowledge was still low and attitudes in terms of mangroves and coral reefs were high. This result showed that students need a model that could enhance knowledge and attitude to conserve mangroves and coral reefs. EECN is one model that have the potential to empower students' knowledge and attitude in protecting the environment.

Keywords: attitude, EECN, knowledge, students, environmental education, conservation of mangroves

Citation: Sigit, D. V., Miarsyah, M., Komala, R., Suryanda, R., Ichsan, I. Z., \& Fadrikal, R. (2020). EECN: Analysis, Potency, Benefit for Students Knowledge and Attitude to Conserve Mangroves and Coral Reefs. International Journal of Instruction, 13(1), 125-138. https://doi.org/10.29333/iji.2020.1318a 


\section{INTRODUCTION}

The damages of mangrove and coral reefs have many negative impacts. One of them is the destruction of coastal and marine ecosystems. Many causes have caused such damage such as the occurrence of plastic pollution in the sea, the construction of various regions by cutting down mangrove forests and taking coral reefs for various human needs. This certainly has a bad impact on the environment. The community should begin to realize not to damage the marine and coastal environment (Cooper, Larson, Dayer, Stedman, \& Decker, 2015; Sangroya \& Nayak, 2017; Shabani, Ashoori, Taghinejad, \& Beyrami, 2013; Strange, Jellesmark, Bladt, Wilson, \& Rahbek, 2011).

People who can protect the marine and coastal environment are of course people who have extensive knowledge of mangroves and coral reefs. This knowledge is important because without extensive knowledge it will be difficult to implement mangrove and environmental conservation. Especially for students who live on the coastal area will be familiar with the environment. Students can play a role in supporting the sustainability of mangroves and coral reefs. One of the ways to instill knowledge is through educational institutions such as schools and universities. Schools and universities can be the right place to teach students various insights about mangroves. When students are given material about mangroves and coral reefs, students are expected to understand it and have an impact on their behavior in protecting the environment. In addition to knowledge, students also implanted various conservation values so as to shape their attitudes in terms of mangrove conservation and coral reefs (Ertz, Karakas, \& Sarigöllü, 2016; Lemus, Seraphin, Coopersmith, \& Correa, 2014; Okur-Berbeglu, 2015; Ozsoy, Memis, \& Temur, 2009; Whitburn, Linklater, \& Milfont, 2018).

Measuring the knowledge and attitudes of students in carrying out mangrove and coral reefs conservation is important to know the current conditions of student profiles. This kind of data collection is important as an evaluation material for teachers and schools in determining how much conservation material is given in learning at school. Based on the data obtained it is expected to be a kind of information for teachers and related parties. There are many ways that teachers can do in instilling a good attitude towards the environment and students' knowledge. One of them is through the Environmental education community network (EECN). This learning model emphasizes the many existing information networks. This learning model has been developed, then the validation and field trials have been carried out and have been declared valid to be used by students from various levels. This model is a learning model that has been successfully developed and has the advantage of being community-based (Sigit, Miarsyah, Komala, \& Suryanda, 2017). This is important because 21st-century learning emphasizes the ability of students to collaborate and communicate (Aslan, 2015; Boholano, 2017; Fauzi \& Fariantika, 2018; Heinrichs, 2016; Kuhlthau, 2010; Sharif \& Cho, 2015; Syabilla, Suryanda, \& Sigit, 2018). Through collaboration and communication, students can exchange information. EECN as a group learning model has the potential that is possible to be discussed and associated with the conditions of students' knowledge and attitudes. 
Based on these problems, it is necessary to measure students' knowledge and attitudes. This is important because it is the basis for teachers in determining the composition of the material to be taught. In addition, the EECN model has the potential to empower students' knowledge and attitudes. The purpose of this study is to measure students' knowledge and attitudes to conserve mangroves and coral reefs and introduce EECN to students and university students. In addition, the EECN potential analysis is carried out as one of the learning models that can be used on students in all levels (Sigit et al., 2017).

\section{METHOD}

This research was conducted in February-April 2019. The sample used was 294 samples from several schools and one university namely Jakarta State University. The schools and one university were in Jakarta, Bekasi, and Bogor city. These school considered to be a place of research because it has many students and is some of the favorite schools Jakarta, Bogor and Bekasi.

The method used in this research is a descriptive method. The data collection technique used is descriptive survey and analysis. The analysis carried out on the EECN learning model has been developed (Sigit et al., 2017). This EECN learning model has been conducted on a small scale trial, and shows an increase in students' knowledge and attitude scores (Sigit et al., 2018). As a model that has been successfully developed, the EECN website (eecn.or.id) is implemented and introduced to students with a wider scale. Implementation to students and the community in wider scale is done by dissemination through social media networks and through messaging applications, then they are invited to visit the EECN website. In addition, an analysis will be carried out in terms of its potential to be used on a broader scale and involve many parties including non-governmental organizations and so on. The analysis was preceded by measuring the students' knowledge and attitudes. Student knowledge instrument used 16 item test questions were valid and reliable. The maximum score that can be obtained by a student is equal to 16. The knowledge test instrument items are developed based on the basic competencies that exist at every level of education from middle school, high school to university. The slices of various basic competencies are summarized into several indicators. This is because knowledge about mangroves and coral reefs is general in nature, so instruments are made the same for various levels. The grid of knowledge test questions can be seen in table 1 .

Table 1

The Indicator of Student Knowledge Test Questions

\begin{tabular}{lll}
\hline No & Indicator & Item \\
\hline 1 & Explain mangrove structure & $1,2,3,4,5,6$ \\
2 & Explain mangrove functions & 7,8 \\
3 & Describe the classification and type of coral reefs & $9,10,14$ \\
4 & Explain the characteristics of coral reefs & $11,12,13,15,16$ \\
\hline
\end{tabular}

Students' attitude instruments are used as many as 18 items and have been declared valid and reliable. This instrument was developed based on other research that has been done in Indonesia regarding mangroves (Sugandini, Rahatmawati, \& Arundati, 2018). The 
maximum score that can be obtained is 90 . The grid of student attitude instruments can be seen in table 2 and the category of knowledge and attitude can be seen in table 3 .

Table 2

The Indicator of Instruments for Student Attitudes

\begin{tabular}{lll}
\hline No & Indicator & Item \\
\hline 1 & Support extension services and seminars on mangroves & $1,2,3,11,12$ \\
2 & Encourage the role of the community in protecting mangroves & $4,5,6,16$ \\
3 & Stop using coral reefs as building and decorative materials & $7,8,9,10,13$ \\
4 & Support community participation in coral reef conservation & $14,15,17,18$ \\
\hline
\end{tabular}

Table 3

The Category of Knowledge and Attitude

\begin{tabular}{ll}
\hline Category & Interval Score \\
\hline Very High & $\mathrm{X}>81.28$ \\
High & $70.64>\mathrm{X}<81.28$ \\
Moderate & $49.36>\mathrm{X} \leq 49.36$ \\
Low & $38.72>\mathrm{X} \leq 49.36$ \\
Very Low & $\mathrm{X} \leq 38.72$ \\
\hline
\end{tabular}

\section{FINDINGS AND DISCUSSION}

Based on the results of measurements, the results of students' knowledge are obtained in maintaining mangroves and coral reefs. The results show that university's students obtain the highest average knowledge score. While, vocational students obtain the lowest value. Average score of knowledge students from all levels were 40.92 (scale 0100) with low category. More details can be seen in table 4.

Table 4

Student Knowledge Score of Coral Reefs and Mangroves

\begin{tabular}{|c|c|c|c|c|c|}
\hline No & Item & $\begin{array}{l}\text { junior high } \\
\text { school }(n=77)\end{array}$ & $\begin{array}{l}\text { senior high } \\
\text { school }(\mathrm{n}=78)\end{array}$ & $\begin{array}{l}\text { vocational } \\
\text { school }(n=62)\end{array}$ & $\begin{array}{l}\text { university } \\
(\mathrm{n}=77)\end{array}$ \\
\hline 1 & Explain the right statement to term the mangrove & 0.43 & 0.50 & 0.48 & 0.48 \\
\hline 2 & Showing certain morphology of the mangrove & 0.06 & 0.04 & 0.03 & 0.04 \\
\hline 3 & $\begin{array}{l}\text { Showing parts of the mangrove with certain } \\
\text { functions }\end{array}$ & 0.84 & 0.79 & 0.81 & 0.97 \\
\hline 4 & Showing part of the breath root & 0.26 & 0.24 & 0.34 & 0.45 \\
\hline 5 & Describe mangrove root types & 0.42 & 0.40 & 0.52 & 0.52 \\
\hline 6 & Explain the concept of knee roots & 0.53 & 0.60 & 0.45 & 0.38 \\
\hline 7 & Explain the role of mangroves & 0.16 & 0.21 & 0.13 & 0.43 \\
\hline 8 & Explain how mangroves adapt to high salt levels & 0.30 & 0.31 & 0.35 & 0.35 \\
\hline 9 & Mention the level of classification of coral reefs & 0.27 & 0.29 & 0.23 & 0.60 \\
\hline 10 & $\begin{array}{l}\text { Explain the causes of corals having different } \\
\text { colors }\end{array}$ & 0.44 & 0.56 & 0.47 & 0.31 \\
\hline 11 & Explain the cause of lagoon formation & 0.06 & 0.18 & 0.18 & 0.18 \\
\hline 12 & $\begin{array}{l}\text { Mention areas that are often encountered by coral } \\
\text { reefs }\end{array}$ & 0.40 & 0.60 & 0.48 & 0.77 \\
\hline 13 & Explain the origin of rocks & 0.48 & 0.35 & 0.31 & 0.51 \\
\hline 14 & $\begin{array}{l}\text { Mention the name of the largest Coral in the } \\
\text { world }\end{array}$ & 0.48 & 0.38 & 0.26 & 0.47 \\
\hline 15 & Mention the ideal temperature for coral reef life & 0.19 & 0.21 & 0.16 & 0.10 \\
\hline 16 & Describe various threats to coral reefs & 0.83 & 0.86 & 0.81 & 0.94 \\
\hline \multicolumn{2}{|c|}{ Average $(0-16)$} & 6.17 & 6.53 & 6.00 & 7.49 \\
\hline \multicolumn{2}{|c|}{ Average $(0-100)$} & 38.56 & 40.81 & 37.50 & 46.81 \\
\hline
\end{tabular}


The second measurement is related to student attitudes in terms of maintaining mangroves and coral reefs. It is seen that the average attitude score of students at the university gets the highest score. Average score of attitudes students from all levels were 74.68 (scale 0-100) with high category. For more details, can be seen in table 5.

Table 5

Score Attitudes of Students and University Students towards Coral Reefs and Mangroves

\begin{tabular}{|c|c|c|c|c|c|}
\hline No & Item & $\begin{array}{l}\text { junior high } \\
\text { school } \\
(n=77)\end{array}$ & $\begin{array}{l}\text { senior high } \\
\text { school } \\
(\mathrm{n}=78)\end{array}$ & $\begin{array}{l}\text { vocational } \\
\text { school } \\
(\mathrm{n}=62)\end{array}$ & $\begin{array}{l}\text { university } \\
(\mathrm{n}=77)\end{array}$ \\
\hline 1 & $\begin{array}{l}\text { Following seminars on mangroves will increase } \\
\text { knowledge about mangrove conservation }\end{array}$ & 4.04 & 4.26 & 4.21 & 4.51 \\
\hline 2 & $\begin{array}{l}\text { I do not like to take counseling about mangrove } \\
\text { conservation because it is a boring thing }\end{array}$ & 3.53 & 3.58 & 3.47 & 3.71 \\
\hline 3 & $\begin{array}{l}\text { I am willing to supply information to the } \\
\text { community about coral reef conservation. }\end{array}$ & 3.47 & 3.64 & 3.60 & 3.91 \\
\hline 4 & $\begin{array}{l}\text { The community must take part in fighting for the } \\
\text { implementation of mangrove conservation }\end{array}$ & 4.19 & 4.47 & 4.26 & 4.64 \\
\hline 5 & $\begin{array}{l}\text { I like the people who carry out coral reef } \\
\text { conservation activities. }\end{array}$ & 4.26 & 4.44 & 4.34 & 4.68 \\
\hline 6 & $\begin{array}{l}\text { I will take part in activities related to mangrove } \\
\text { conservation }\end{array}$ & 3.35 & 3.54 & 3.61 & 4.04 \\
\hline 7 & $\begin{array}{l}\text { I like to collect home displays made from coral } \\
\text { reefs. }\end{array}$ & 2.90 & 3.31 & 2.77 & 3.74 \\
\hline 8 & $\begin{array}{l}\text { Coral reefs can continue to be used as building } \\
\text { materials even though the population is declining }\end{array}$ & 3.51 & 4.00 & 3.69 & 4.45 \\
\hline 9 & Coral reefs are very beautiful if used as decoration & 2.04 & 2.60 & 2.42 & 3.38 \\
\hline 10 & $\begin{array}{l}\text { Destruction of coral reefs will not disturb the } \\
\text { balance of the ecosystem. }\end{array}$ & 3.88 & 4.28 & 4.00 & 4.60 \\
\hline 11 & $\begin{array}{l}\text { I will not care about the latest issues about } \\
\text { mangrove. }\end{array}$ & 3.27 & 3.73 & 3.40 & 4.10 \\
\hline 12 & $\begin{array}{l}\text { I like to see mangroves being used as tourist } \\
\text { attractions. }\end{array}$ & 2.18 & 2.08 & 2.08 & 2.47 \\
\hline 13 & $\begin{array}{l}\text { If there is an opportunity, I will break the coral reefs } \\
\text { in the sea to collect. }\end{array}$ & 4.29 & 4.33 & 4.21 & 4.77 \\
\hline 14 & $\begin{array}{l}\text { I am happy if the conservation center really strives } \\
\text { for the conservation of mangroves and coral reefs. }\end{array}$ & 4.14 & 4.51 & 4.42 & 4.74 \\
\hline 15 & $\begin{array}{l}\text { Coral reefs will be abundant if there is development } \\
\text { in the coastal area. }\end{array}$ & 2.55 & 2.42 & 2.45 & 1.81 \\
\hline 16 & $\begin{array}{l}\text { The destruction of mangrove areas on a large scale } \\
\text { will have an impact on the imbalance of the coastal } \\
\text { ecosystem. }\end{array}$ & 3.95 & 4.36 & 4.11 & 4.62 \\
\hline 17 & $\begin{array}{l}\text { I feel satisfied if something damages the coral reefs } \\
\text { is punished legally. }\end{array}$ & 3.79 & 4.05 & 4.05 & 4.26 \\
\hline \multirow[t]{3}{*}{18} & $\begin{array}{l}\text { I will report to the authorities if there are tourists } \\
\text { who damage the coral reef. }\end{array}$ & 4.09 & 4.10 & 4.27 & 3.96 \\
\hline & Average (0-90) & 63.43 & 67.71 & 65.37 & 72.38 \\
\hline & Average score $(0-100)$ & 70.47 & 75.23 & 72.63 & 80.42 \\
\hline
\end{tabular}

In addition to the students' knowledge and attitudes that have been measured, added data were also obtained relating to mangrove and coral reef conservation activities. There are two questions raised to the respondent which are related to extracurricular activities 
taken at school and their interest in traveling. The question was asked to the respondent to know more deeply the characteristics of the respondents who filled out the instrument. This is needed to add data for further analysis. For more details, can be seen in table 6 .

Table 6

The condition of students

\begin{tabular}{|c|c|c|c|c|c|c|}
\hline No & Item & Answer & $\begin{array}{l}\text { junior high } \\
\text { school } \\
(\mathrm{n}=77)\end{array}$ & $\begin{array}{l}\text { senior high } \\
\text { school } \\
(\mathrm{n}=78)\end{array}$ & $\begin{array}{l}\text { vocational } \\
\text { school } \\
(\mathrm{n}=62)\end{array}$ & $\begin{array}{l}\text { university } \\
(\mathrm{n}=77)\end{array}$ \\
\hline 1 & $\begin{array}{l}\text { Are you taking part in a study / } \\
\text { extracurricular group on }\end{array}$ & Yes & 19 & 26 & 2 & 44 \\
\hline \multirow{3}{*}{2} & science or the environment? & No & 58 & 52 & 60 & 33 \\
\hline & Where do you prefer to travel? & Mountain & 40 & 44 & 33 & 42 \\
\hline & & Beach & 37 & 34 & 29 & 35 \\
\hline
\end{tabular}

Based on table 5, students at the university level participate in extracurricular activities in the field of natural science and the environment while the lowest percentage is in vocational school students. Then, for the interest in traveling students who go to the mountain are mostly obtained by senior high school students, while the lowest is by vocational school students. Besides going to the mountains, many students also like to travel to the beach. junior high school students have the most number with interest in traveling to the coast, while at least vocational school students.

Based on the results of measurements in table 4, 5 and refer from category in table 3 , it can be concluded that students' knowledge in all level have low category. Then attitudes in maintaining mangroves and coral reefs are high, except junior high school students have moderate category. Low category of knowledge but a high category attitude showed that information obtained by students about coral reefs and mangroves is still needed. This makes it necessary to develop further various media and teaching materials related to mangroves and coral reefs. So that knowledge becomes higher and good attitudes will be better. In the knowledge aspect, some aspects are still low, for example, which relate to the characteristics of coral reefs. This is because students and undergraduate students do not get detailed explanations about environment from the teacher during learning, such as in Biology learning in schools (Ali \& Arif, 2019; Derevenskaia, 2014; Havu-Nuutinen \& Niikko, 2014; Hidayati, Pangestuti, \& Prayitno, 2019; Kinay \& Bagceci, 2016; Permana \& Chamisijatin, 2019; Srisumra, Nontamolee, \& Srijamon, 2014; Xia, 2017). Besides, on the aspect of student aspects that have a low score, one of them is that there are still many students who do not care about the habits of people who make coral reefs as ornaments or building materials. This is because there are still many students who do not understand the danger of making coral reefs as ornaments. Students should have a good attitude in the context of protecting the environment.

All problems of students' knowledge and attitudes can be solved by using one of the learning models namely Environmental Education Community Network (EECN). This learning model is very relevant for use by teachers in empowering students' knowledge and attitudes. This EECN learning model has been conducted on a small-scale trial, and 
shows an increase in students' knowledge and attitude scores (Sigit et al., 2018). EECN model has been introduced and applied to students. The following are some of the characteristics offered by the EECN model can be seen in table 7. Then EECN learning model syntax and activities can be seen in table 8 .

Table 7

EECN Characteristics

\begin{tabular}{lll}
\hline No & Indicator & Characteristics \\
\hline 1 & $\begin{array}{l}\text { Complete learning media } \\
\text { Location of learning } \\
\text { implementation }\end{array}$ & $\begin{array}{l}\text { Complete learning media, consisting of textbook websites and worksheets } \\
\text { It can be done outside the classroom and allows it to be carried out in } \\
\text { certain areas such as the ecotourism area } \\
\text { Can be done outside the hours of learning in school, more flexible and } \\
\text { not bound to the time of learning in class } \\
\text { This model allows various levels of students to take part in both } \\
\text { elementary, middle and high school to university students } \\
\text { Facilitate environmental learning both in the classroom or outside the } \\
\text { classroom, while also helping students understand things about } \\
\text { mangroves and coral reefs }\end{array}$ \\
& $\begin{array}{l}\text { Students involved } \\
\text { after learning from }\end{array}$ &
\end{tabular}

Source: (Sigit et al., 2017)

Table 8

EECN Learning Model Syntax and Activities

\begin{tabular}{|c|c|c|}
\hline No & EECN Syntax & $\begin{array}{l}\text { Activities to conserve coral reef and } \\
\text { mangrove }\end{array}$ \\
\hline 1 & $\begin{array}{l}\text { Teacher (Instructor / Lecture) divides students into } \\
\text { several groups }\end{array}$ & $\begin{array}{l}\text { The teacher divides students into several } \\
\text { groups }\end{array}$ \\
\hline 2 & $\begin{array}{l}\text { Students and their groups discuss the environmental } \\
\text { problems that will be solved }\end{array}$ & $\begin{array}{l}\text { Students in this case agreed to solve the } \\
\text { problems of coral reefs and mangroves }\end{array}$ \\
\hline 3 & $\begin{array}{l}\text { Students do plan learning activities, to solve these } \\
\text { environmental problems (activities can be indoor or } \\
\text { outdoor) }\end{array}$ & $\begin{array}{l}\text { Planning activities on the thousand } \\
\text { islands }\end{array}$ \\
\hline 4 & $\begin{array}{l}\text { The teacher coordinates with students and various } \\
\text { relevant parties about the plan of learning activities }\end{array}$ & $\begin{array}{l}\text { The teacher coordinates with students } \\
\text { and community leaders in the thousand } \\
\text { islands to carry out mangrove and coral } \\
\text { reef conservation activities }\end{array}$ \\
\hline 5 & $\begin{array}{l}\text { The teacher gives instructions and participates in the } \\
\text { implementation of learning activities }\end{array}$ & $\begin{array}{l}\text { The teacher gives brief material about } \\
\text { mangroves and coral reefs, and } \\
\text { participate }\end{array}$ \\
\hline 6 & $\begin{array}{l}\text { Students observe and write the report results of } \\
\text { observations, and conduct analysis during the } \\
\text { learning activities. Students are also creating } \\
\text { products to learning activities being carried out }\end{array}$ & $\begin{array}{l}\text { Students carry out mangrove and coral } \\
\text { reef planting activities and record the } \\
\text { results of activities on a piece of paper } \\
\text { and record the results of the analysis. } \\
\text { The product created is a record of } \\
\text { activities (a kind of research paper) }\end{array}$ \\
\hline 7 & $\begin{array}{l}\text { Students present their work in front of their friends } \\
\text { in groups about the observations of the learning } \\
\text { activities and other groups give questions or } \\
\text { comments to the groups that present }\end{array}$ & $\begin{array}{l}\text { Students made presentations and other } \\
\text { groups asked about mangroves and coral } \\
\text { reefs and commented on the EECN coral } \\
\text { reefs and mangrove website }\end{array}$ \\
\hline 8 & The teacher evaluates these learning activities & $\begin{array}{l}\text { The teacher gave a test about mangroves } \\
\text { and coral reefs }\end{array}$ \\
\hline 9 & $\begin{array}{l}\text { Students give comments and conclude the main } \\
\text { points of learning activities that have been carried } \\
\text { out (can be directly or through the website or social } \\
\text { media) }\end{array}$ & $\begin{array}{l}\text { Student representatives were asked to } \\
\text { conclude the activity and comment on } \\
\text { the EECN website }\end{array}$ \\
\hline
\end{tabular}


Note: EECN learning model can be used in other environmental problems such as waste recycling, green consumerism, eco-label, climate change etc. Not only limited to mangrove and coral reef problems. EECN can also be used at all levels of education from elementary school, junior and senior high school and university

Based on the advantages possessed, EECN has broader potential to improve students' knowledge and attitudes in environmental learning. EECN has good potential to be used on a broader scale and a greater number of people and involves many parties such as non-governmental organizations, government, informal education institutions and so on. This is because environmental learning must be carried out contextually and students are invited to go directly to the field (Gündüz, Alemdağ, Yaşar, \& Erdem, 2016; Kartikaningtyas, Kusmayadi, \& Riyadi, 2018; Koutsoukos, Fragoulis, \& Valkanos, 2015). Based on the data from the measurement of knowledge in table 1, students cannot perfectly answer many questions. This is because their insights are less about mangroves and fewer reefs. This narrow insight can be improved by learning that is more active and in accordance with what students want (Camacho \& Legare, 2015; Juhanda \& Maryanto, 2018; Supriyatin, Nurnawati, \& Heryanti, 2016; Uzun, 2012).

In this study, the measurement results of students' knowledge still low and attitudes that are high showed that the use of EECN is still not maximal and needs to be stressed again. Learning using EECN has characteristics that are very suitable for use by teachers who want to improve their students' knowledge, in this case regarding the conservation of mangroves and coral reefs. Students can interact with other students from various backgrounds and are taught to work together. This has an impact in addition to increase knowledge as well as having an impact on the ability of other students such as the ability to collaborate and communicate that is very much needed in 21 st-century learning (Quieng, Lim, \& Lucas, 2015; Sharif \& Cho, 2015). EECN in its learning emphasizes collaboration aspects in the community because that is the superiority of EECN itself. Students who are able to collaborate are expected to have a conservative attitude towards the environment (Haddow, Xia, \& Willson, 2017; Karsten et al., 2015; Nissim, Weissblueth, Scott-Webber, \& Amar, 2016; Sandberg \& Ohman, 2011).

The attitude of students based on the measurement results in table 2 shows that between levels of education are not too different in their attitude scores. Even so, they can access various information about mangroves and coral reefs on the internet (Brown, 2017; Jiang et al., 2017; Lee, 2014; Nugraini, Choo, Hin, \& Hoon, 2013; Reyna, Hanham, \& Meier, 2018; Suhendar \& Wahyuni, 2018; Wolfson \& Funke, 2014; Yusop \& Sumari, 2013). The amount of information obtained from the internet can change one's knowledge and attitudes in maintaining marine ecosystems.

EECN has a role in providing information through various media that have been developed, such as websites. Through the website, learning that uses this EECN model can take place at any time without time constraints. Students can access the information anywhere and anytime they want. This certainly facilitates the teacher in teaching (Fatih, 2016; Fitriani, Adisyahputra, \& Komala, 2018; Nugraini et al., 2013; Ramdhani \& Muhammadiyah, 2015). From this reason, it can be said that the EECN model has great potential in environmental learning. 
EECN is a product development model but has only been used on a small scale. So more massive use is needed, for example, applied in learning at school at every level. In a wider range of uses, EECN can be used in more general activities but also in class learning. For example, preservation activities carried out by certain institutions, can use various media that have been developed in EECN. Various components can also access this information openly and the information provided is easy to understand. This will have an impact on broad information to the community and make the community care about the environment (Choudri et al., 2017; Istiana \& Awaludin, 2018; Ito \& Kawazoe, 2015; Norman, Nordin, Din, \& Ally, 2016; Nurwidodo, Hendayana, Hindun, \& Sarimanah, 2018; Paço \& Rodrigues, 2016; Siphai, 2015; Yedla \& Park, 2017).

\section{CONCLUSION}

Based on the results of the study, students' knowledge is still low category from all levels. Students attitude have high category, except in junior high school have moderate category. It can be concluded that the score of students' knowledge and attitudes in maintaining mangroves and coral reefs is still needs to be improved. The results of the introduction and application of EECN to students show that EECN has advantages that can be used to improve students' knowledge and attitudes. The use of EECN must be emphasized again to become more frequent and intensive at least at the end of each semester. In a broader use, EECN can be used in community activities so that people get a broader insight into mangroves.

\section{ACKNOWLEDGMENT}

Thank you for Indonesia Ministry of Research, Technology, and Higher Education (Kemenristekdikti) for funding this research in 2019.

\section{REFERENCES}

Ali, A., \& Arif, W. P. (2019). Developing of guidance for laboratory practice of islamic science-integrated plant anatomy-physiology. Biosfer: Jurnal Pendidikan Biologi, 12(1), 70-82. https://doi.org/10.21009/biosferjpb.v12n1.70-82.

Aslan, S. (2015). Is learning by teaching effective in gaining 21 st century skills? The views of pre-service science teachers. Kuram ve Uygulamada Egitim Bilimleri, 15(6), 1441-1457. https://doi.org/10.12738/estp.2016.1.0019.

Boholano, H. B. (2017). Smart social networking: 21st century teaching and learning skills. Research in Pedagogy, 7(1), 21-29. https://doi.org/10.17810/2015.45.

Brown, N. (2017). Updating assessment styles: Website development rather than report writing for project based learning courses. Advances in Engineering Edu., 6(2), 1-16.

Camacho, D. J., \& Legare, J. M. (2015). Opportunities to create active learning techniques in the classroom. Journal of Instructional Research, 4, 38-45.

Choudri, B. S., Baawain, M., Al-Zeidi, K., Al-Nofli, H., Al-Busaidi, R., \& Al-Fazari, K. (2017). Citizen perception on environmental responsibility of the corporate sector in rural areas. Environment, Development and Sustainability, 19(6), 2565-2576. 
https://doi.org/10.1007/s10668-016-9855-y.

Cooper, C., Larson, L., Dayer, A., Stedman, R., \& Decker, D. (2015). Are wildlife recreationists conservationists? Linking hunting, birdwatching, and pro-environmental behavior. Journal of Wildlife Management, 79(3), 446-457. https://doi.org/10.1002/jwmg.855.

Derevenskaia, O. (2014). Active learning methods in environmental education of students. Procedia - Social and Behavioral Sciences, 131, 101-104. https://doi.org/10.1016/j.sbspro.2014.04.086.

Ertz, M., Karakas, F., \& Sarigöllü, E. (2016). Exploring pro-environmental behaviors of consumers: An analysis of contextual factors, attitude, and behaviors. Journal of Business Research, 69(10), 3971-3980. https://doi.org/10.1016/j.jbusres.2016.06.010.

Fatih, M. T. uuml rker. (2016). Design process for online websites created for teaching Turkish as a foreign language in web based environments. Educational Research and Reviews, 11(8), 642-655. https://doi.org/10.5897/ERR2015.2511.

Fauzi, A., \& Fariantika, A. (2018). Courses perceived difficult by undergraduate students majoring in biology. Biosfer: Jurnal Pendidikan Biologi, 11(2), 78-89. https://doi.org/10.21009/biosferjpb.v11n2.78-89.

Fitriani, U., Adisyahputra, A., \& Komala, R. (2018). Eco-friendly website development in biology learning based on project activities on environmental pollution. Biosfer: Jurnal Pendidikan Biologi, 11(1), 32-46. https://doi.org/10.21009/biosferjpb.11-1.4.

Gündüz, A. Y., Alemdağ, E., Yaşar, S., \& Erdem, M. (2016). Design of a problembased online learning environment and evaluation of its effectiveness. The Turkish Online Journal of Educational Technology, 15(3), 49-57. https://doi.org/10.1017/CBO9781107415324.004.

Haddow, G., Xia, J., \& Willson, M. (2017). Collaboration in the humanities, arts and social sciences in Australia. Australian Universities' Review, 59(1), 24.36.

Havu-Nuutinen, S., \& Niikko, A. (2014). Finnish primary school as a learning environment for six-year-old preschool children. European Early Childhood Education Research Journal, 22(5), 621-636. https://doi.org/10.1080/1350293X.2014.969084.

Heinrichs, C. R. (2016). Exploring the influence of 21st century skills in a dual language program: A case study. International Journal of Teacher Leadership Heinrichs Exploring the Influence, 37(1), 37-56.

Hidayati, N., Pangestuti, A. A., \& Prayitno, T. A. (2019). Edmodo mobile: Developing e-module biology cell for online learning community. Biosfer: Jurnal Pendidikan Biologi, 12(1), 94-108. https://doi.org/10.21009/biosferjpb.v12n1.94-108.

Istiana, R., \& Awaludin, M. T. (2018). Enhancing biology education students ability to solve problems in environmental science material through inquiri model-based lesson study. Biosfer: Jurnal Pendidikan Biologi, 11(1), 57-66. 
https://doi.org/10.21009/biosferjpb.11-1.6.

Ito, H., \& Kawazoe, N. (2015). Active learning for creating innovators: Employability skills beyond industrial needs. International Journal of Higher Education, 4(2), 81-91. https://doi.org/10.5430/ijhe.v4n2p81.

Jiang, B., Yang, J., Lv, Z., Tian, K., Meng, Q., \& Yan, Y. (2017). Internet cross-media retrieval based on deep learning. Journal of Visual Communication and Image Representation, 48, 356-366. https://doi.org/10.1016/j.jvcir.2017.02.011.

Juhanda, A., \& Maryanto, Y. (2018). The emergence of biological problems in electronic school books (BSE) class $\mathrm{x}$ reviewed from the scientific knowledge domain of scientific literacy. Biosfer: Jurnal Pendidikan Biologi, 11(2), 121-125. https://doi.org/10.21009/biosferjpb.v11n2.121-125.

Karsten, K., Coddington, D. M., Lehman, R. M., Pierce, C., Tom, M., \& Gallo-Silver, L. (2015). Facilitating interprofessional collaboration through eportfolio: A pilot study. International Journal of ePortfolio, 5(2), 181-188.

Kartikaningtyas, V., Kusmayadi, T. A., \& Riyadi, R. (2018). The effect of brain based learning with contextual approach viewed from adversity quotient. Journal of Physics: Conference Series, 1022(1), 012014.

Kinay, I., \& Bagceci, B. (2016). The investigation of the effects of authentic assessment approach on prospective teachers' problem-solving skills. International Education Studies, 9(8), 51-59. https://doi.org/10.5539/ies.v9n8p51.

Koutsoukos, M., Fragoulis, I., \& Valkanos, E. (2015). Connection of environmental education with application of experiential teaching methods: A case study from Greece. International Education Studies, 8(4), 23-28. https://doi.org/10.5539/ies.v8n4p23.

Kuhlthau, C. C. (2010). Guided inquiry: School libraries in the 21st century. School Libraries Worldwide, 16(1), 17-28.

Lee, S. M. (2014). The relationships between higher order thinking skills, cognitive density, and social presence in online learning. Internet and Higher Education, 21, 4152. https://doi.org/10.1016/j.iheduc.2013.12.002.

Lemus, J. D., Seraphin, K. D., Coopersmith, A., \& Correa, C. K. V. (2014). Infusing Traditional knowledge and ways of knowing into science communication courses at the university of Hawai'i. Journal of Geoscience Education, 62(1), 5-10. https://doi.org/10.5408/12-416.1

Nissim, Y., Weissblueth, E., Scott-Webber, L., \& Amar, S. (2016). The effect of a stimulating learning environment on pre-service teachers' motivation and 21 st century skills. Journal of Education and Learning, 5(3), 29-39. https://doi.org/10.5539/jel.v5n3p29.

Norman, H., Nordin, N., Din, R., \& Ally, M. (2016). Modeling learner situation awareness in collaborative mobile web 2.0 learning. Malaysian Online Journal of 
Educational Technology, 4(1), 32-56.

Nugraini, S. H., Choo, K. A., Hin, H. S., \& Hoon, T. S. (2013). Students' feedback of eav biology website and the learning impact towards biology. Procedia - Social and Behavioral Sciences, 103, 860-869. https://doi.org/10.1016/j.sbspro.2013.10.408.

Nurwidodo, N., Hendayana, S., Hindun, I., \& Sarimanah, E. (2018). Strategies for establishing networking with partner schools for implementing lesson study in Indonesia. Jurnal Pendidikan Biologi Indonesia, 4(1), 11-22. https://doi.org/10.22219/jpbi.v4i1.5489 11.

Okur-Berbeglu, E. (2015). The effect of ecopodagogy-based environmental education on environmental attitude of in-service teachers. International Electronic Journal of Environmental Education, 5(2), 86-110. https://doi.org/10.18497/iejee-green.09988.

Ozsoy, G., Memis, A., \& Temur, T. (2009). Metacognition, study habits and attitudes. International Electronic Journal of Elementary Education, 2(1), 154-166.

Paço, A., \& Rodrigues, R. G. (2016). Environmental activism and consumers' perceived responsibility. International Journal of Consumer Studies, 40(4), 466-474. https://doi.org/10.1111/ijcs.12272.

Permana, F. H., \& Chamisijatin, L. (2019). Project-based learning through edmodo: improving critical thinking and histology concepts. Biosfer: Jurnal Pendidikan Biologi, 12(1), 58-69. https://doi.org/10.21009/biosferjpb.v12n1.58-69.

Quieng, M. C., Lim, P. P., \& Lucas, M. R. D. (2015). 21st century-based soft skills: Spotlight on non-cognitive skills in a cognitive-laden dentistry program. European Journal of Contemporary Education, 11(1), 72-81. https://doi.org/10.13187/ejced.2015.11.72.

Ramdhani, M. A., \& Muhammadiyah, H. (December, 2015). The criteria of learning media selection for character education in higher education. Paper presented at International Conference of Islamic Educatios in Shoutheast Asia, Malang, Indonesia.

Reyna, J., Hanham, J., \& Meier, P. (2018). The internet explosion, digital media principles and implications to communicate effectively in the digital space. E-Learning and Digital Media, 15(1), 36-52. https://doi.org/10.1177/2042753018754361.

Sandberg, K. W., \& Ohman, G. (2011). Learning in innovation development. Procedia Social and Behavioral Sciences, 28, 379-383. https://doi.org/10.1016/j.sbspro.2011.11.072.

Sangroya, D., \& Nayak, J. K. (2017). Factors influencing buying behaviour of green energy consumer. Journal of Cleaner Production, 151, 393-405. https://doi.org/10.1016/j.jclepro.2017.03.010.

Shabani, N., Ashoori, M., Taghinejad, M., \& Beyrami, H. (2013). The study of green consumers' characteristics and available green sectors in the market. International Research Journal of Applied and Basic Sciences, 4(7), 1880-1883. 
Sharif, A., \& Cho, S. (2015). 21st-century instructional designers: bridging the perceptual gaps between identity, practice, impact and professional development. RUSC. Universities and Knowledge Society Journal, 12(3), 72-85. https://doi.org/10.7238/rusc.v12i3.2176.

Sigit, D. V., Miarsyah, M., Komala, R., \& Suryanda, A. (2017). Developing communitybased media on environmental education to conserve mangrove and coral ecosystem in Kepulauan Seribu. In Ideas for 21st Century Education: Proceedings of The Asian Education Symposium (AES 2016) (pp. 131-134). London: Taylor \& Francis Group.

Sigit, D. V., Miarsyah, M., Komala, R., Suryanda, A., Fadrikal, R., \& Ichsan, I. Z. (2018). Improvement of knowledge and attitude in conservation of mangrove and coral reefs through environmental education community network model. In 3rd International Conference on Mathematics, Science, Education and Engineering (ICOMSET2018).

Siphai, S. (2015). Influences of moral, emotional and adversity quotient on good citizenship of Rajabhat university's students in the northeast of Thailand. Educational Research and Reviews, 10(17), 2413-2421. https://doi.org/10.5897/ERR2015.2212.

Srisumra, J., Nontamolee, W., \& Srijamon, S. (2014). Cooperative learning activities in arts of prathom suksa 4 students Khon Kaen university demonstration school primary section (modindaeng). Procedia - Social and Behavioral Sciences, 112(Iceepsy 2013), 677-682. https://doi.org/10.1016/j.sbspro.2014.01.1217.

Strange, N., Jellesmark, B., Bladt, J., Wilson, K. A., \& Rahbek, C. (2011). Conservation policies and planning under climate change. Biological Conservation, 144(12), 29682977. https://doi.org/10.1016/j.biocon.2011.08.022

Sugandini, D., Rahatmawati, I., \& Arundati, R. (2018). Environmental attitude on the adoption decision mangrove conservation: An empirical study on communities in special region of Yogyakarta, Indonesia. Review of Integrative Business and Economics Research, 7(1), 266-275.

Suhendar, S., \& Wahyuni, A. (2018). Achievement and response of students at favorite junior high schools in sukabumi on trends in international mathematics and science study (TIMSS) questions. Biosfer: Jurnal Pendidikan Biologi, 11(2), 126-133. https://doi.org/10.21009/biosferjpb.v11n2.126-133.

Supriyatin, S., Nurnawati, N., \& Heryanti, E. (2016). Pengaruh penerapan active, joyful, and effective learning (AJEL) pada materi perubahan lingkungan terhadap sikap peduli lingkungan siswa. Biosfer: Jurnal Pendidikan Biologi, 9(2), 69-75. https://doi.org/10.21009/biosferjpb.9-2.10.

Syabilla, Y. A., Suryanda, A., \& Sigit, D. V. (2018). A correlation between self concept and procrastination based on gender in neuroscience perspective. Biosfer: Jurnal Pendidikan Biologi, 11(2), 114.120. https://doi.org/10.21009/biosferjpb.v11n2.114-120.

Uzun, N. (2012). A sample of active learning application in science education: The thema "cell" with educational games. Procedia - Social and Behavioral Sciences, 46, 
2932-2936. https://doi.org/10.1016/j.sbspro.2012.05.592.

Whitburn, J., Linklater, W. L., \& Milfont, T. L. (2018). Exposure to urban nature and tree planting are related to pro-environmental behavior via connection to nature, the use of nature for psychological restoration, and environmental attitudes. Environment and Behavior, 51(7), 787-810. https://doi.org/10.1177/0013916517751009.

Wolfson, T., \& Funke, P. N. (2014). Communication, class and concentric media practices: Developing a contemporary rubric1. New Media and Society, 16(3), 363-380. https://doi.org/10.1177/1461444813481199

Xia, B. S. (2017). An In-depth analysis of teaching themes and the quality of teaching in higher education: Evidence from the programming education environments. International Journal of Teaching and Learning in Higher Education, 29(2), 245-254.

Yedla, S., \& Park, H. S. (2017). Eco-industrial networking for sustainable development: review of issues and development strategies. Clean Technologies and Environmental Policy, 19(2), 391-402. https://doi.org/10.1007/s10098-016-1224-x.

Yusop, F. D., \& Sumari, M. (2013). The Use of Social Media Technologies among Malaysian Youth. Procedia - Social and Behavioral Sciences, 103, 1204-1209. https://doi.org/10.1016/j.sbspro.2013.10.448. 